\title{
食物嗜好に関する意識調査
}

園 田 真 人, 馬 場 香代子*

北九州市環滰衛生研究所, 九州女子大学*

\section{Studies on Food Preference in Children, Adolescents and the Elderly}

Makoto Sonoda and Kayoko Baba*

The Kitakyushu Municipal Institute of Environmental Nealth Sciences

* Kyushu Women's University

\section{は じめに}

人間の食物嫩好飞影響を及ぼす因子は, きわめて多彩であり, 年齢, 性別, 健康状態, 生活習慣, 栄養知 識, マスコミの影響, 摂食の経験などが考允られるが, 暂好調査に扎いては, その方法, 時期, 環境も成績を 大きく左右するであうう。しかしながら，食物墸好は人間の食生活を左右する因子ですあるので，個人や地域 住民あるいは国民の食生活や栄養状沉を把握する上で，避けて通れない課題である。

われわれは, 今回に至るまで, 幼稚園児 ${ }^{1) 2}$, 学生, 生徒 ${ }^{23)}$, 妊婦5), 老人(1)7)などを対象として, 食物喍好 の調査を行い, 老人の毎日食べたい物は, 野菜, 果物が上位を占めるが, 高校生は, 果物, アイスクリーム, 牛乳が上位を占め, 老人と若者の食物嗼好は，かなり異なることをみとめた。

本調査は，ひとつの喏好調査の方法としていちばん食べたい物，いちばん食べたくない物はなにか，という 質問を行い, 分析を計画し, 小学生, 成人 (18歳から33歳までの年齡), 老人を対象に調查し, 考察を加えた ので，その結果を報告する。

\section{調查対象及び調查方法}

調査対象は, 北九州市の某小学校 6 年生 (男子68例, 女子85例), 某女子短期大学学生519例, 18歳より33歳 までの地方公務員 (男子173例, 女子60例), 65歳上り80歳までの年齢層の老人クラブ会員（男子183例, 女子 279例)，計1,367例である。

調査方法は, 調査用紙を作成し, 年齢, 性別, 及 びいちばん食べたい物, いちばん食べたくない物を， それぞれひとつだけ記入させて，すぐに回収した。

調査期日は, 昭和 54 年 $4 \sim 6$ 月であり, 時間は, 午後 $1 \sim 2$ 時に行った。但し, 保母においては, 午 前11時に行った。

\section{調查成績及び考察}

1. いちばん食べたい物

(1) 小学生について

本調查の小学生男子の「いちばん食べたい物」は, 表 1 に示すように，肉料理 (26.5\%)，果物（19.1 \%), アイスクリーム (13.2\%), とくになし(13.2 表 1 小学生男子のいちばん食べたい物

\begin{tabular}{|c|c|c|}
\hline 食 品 名 & 例 数 & $\begin{array}{c}\text { 百分率 } \\
(\%)\end{array}$ \\
\hline 料 理 & 18 & 26.5 \\
\hline 果 & 13 & 19.1 \\
\hline アイスクリーム & 9 & 13.2 \\
\hline とくになし & 9 & 13.2 \\
\hline デザート & 4 & 5.9 \\
\hline カレーライス & 3 & 4.4 \\
\hline 司 & 3 & 4.4 \\
\hline 冷たい飲又物 & 3 & 4.4 \\
\hline ラ $-x$ 冫 & 2 & 2.9 \\
\hline らな 井 & 1 & 1.5 \\
\hline ハンバーガー & 1 & 1.5 \\
\hline 壳びフライ & 1 & 1.5 \\
\hline 生 野 菜 & 1 & 1.5 \\
\hline 計 & 68 & 100.0 \\
\hline
\end{tabular}


表 2 小学生女子のいちばん食べたい物

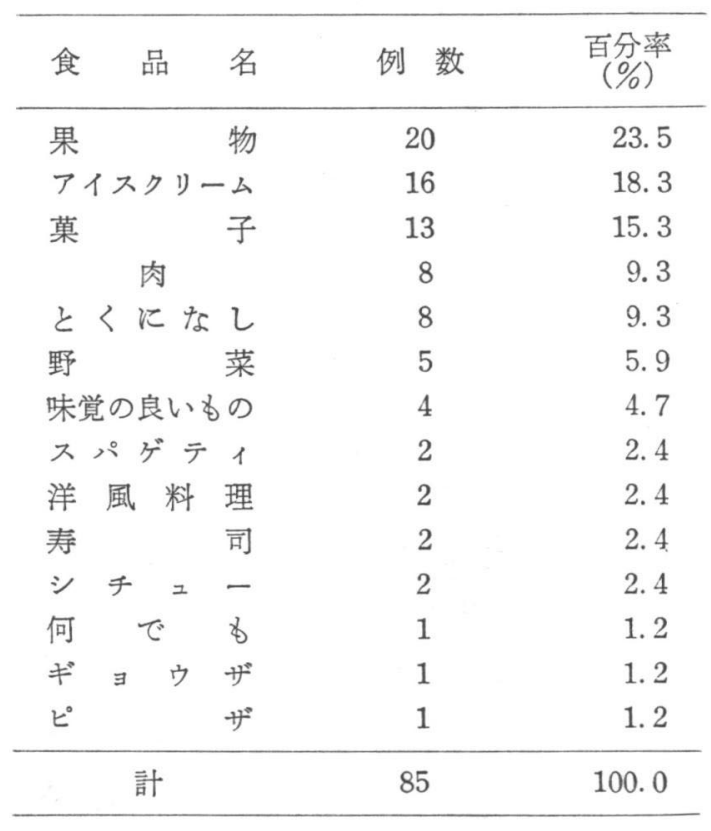

\%) が上位を占めている。

小学生女子に护け「いちぱん食べたい物」は, 表 2 に示すように，果物 $(23.5 \%)$ ， アイスクリー 么 $(18.8 \%)$, 菓子 $(15.3 \%)$, 肉 $(9.3 \%)$, とくに なし $(9.3 \%)$ が上位を占めている。

小学生の食物嗜好は, 学校給食の調査として行わ れることが多く，以前行ったわれわれの調査3) では， 小学生の好きな食品は, リンゴ, 八厶, トマト, 豆 腐か゚上位を占めており，本調査とはやや異なってい る。

具体的な品名をあげて, その中から選ばせた調 查 ${ }^{3)}$ と本調査のように抽象的な質問調査の差かもし れないので, 今後の検討課題である。

本調査に拈ける小学生の「いちばん食べたい物」 の分布は，男女差はほとんどみられない。

(2) 地方公務員について

18〜28歳の男子地方公務員に叔ける「いらばん食 ベたい物」は，表 3 に示すように，果物 $(26.6 \%)$ ，肉 $(17.3 \%)$ ，とくになし $(13.3 \%)$ 菓子 $(10.4 \%)$ が上 位を占めている。

20３3 歳の女子地方公務員に拈ける「いちばん食べたい物」は，表 4 に示すように，菓子 (26.7\%), 果物 $(26.7 \%)$ ，アイスクリーム $(13.3 \%)$, 肉 $(6.6 \%)$ が上位を占めている。
表 3 18～28歳の公務員男子の食べたい物

\begin{tabular}{|c|c|c|c|c|}
\hline 食至 & 品 & 名 & 例 数 & $\begin{array}{l}\text { 百分率 } \\
(\%)\end{array}$ \\
\hline \multirow[t]{2}{*}{ 果 } & & 物 & 46 & 26.6 \\
\hline & 肉 & & 30 & 17.3 \\
\hline \multirow{2}{*}{\multicolumn{2}{|c|}{$\begin{array}{l}\text { とくにな } \\
\text { 菓 }\end{array}$}} & L & 23 & 13. 3 \\
\hline & & 子 & 18 & 10. 4 \\
\hline \multirow{3}{*}{$\begin{array}{l}\text { 米 } \\
\text { 麵 }\end{array}$} & 料 & 理 & 14 & 8.1 \\
\hline & & 類 & 13 & 7.5 \\
\hline & 魚 & & 10 & 5.8 \\
\hline \multicolumn{2}{|l|}{ 軽 } & 食 & 8 & 4. 6 \\
\hline \multicolumn{2}{|c|}{ 大 豆 製 } & 品 & 3 & 1.6 \\
\hline \multicolumn{2}{|c|}{ 野 } & 菜 & 2 & 1.2 \\
\hline \multicolumn{2}{|l|}{ 夕 } & 食 & 2 & 1.2 \\
\hline \multicolumn{2}{|c|}{ 茶わん蒸 } & ᄂ & 1 & 0.6 \\
\hline \multicolumn{2}{|l|}{ チ } & ズ & 1 & 0.6 \\
\hline \multicolumn{2}{|l|}{ 豆 } & 腐 & 1 & 0.6 \\
\hline \multicolumn{3}{|c|}{ 味覚の良いもの } & 1 & 0.6 \\
\hline \multicolumn{3}{|c|}{ 計 } & 173 & 100.0 \\
\hline
\end{tabular}

表 4 20～33歳の公務員女子のいちばん 食べたい物

\begin{tabular}{|c|c|c|c|}
\hline 食 & 品 名 & 例 数 & $\begin{array}{c}\text { 百分率 } \\
(\%)\end{array}$ \\
\hline 菓 & 子 & 16 & 26.7 \\
\hline 果 & 物 & 16 & 26.7 \\
\hline \multicolumn{2}{|c|}{ アイスクリーム } & 8 & 13.3 \\
\hline \multicolumn{2}{|c|}{ 肉 } & 4 & 6.6 \\
\hline 寿 & 司 & 3 & 5.0 \\
\hline 野 & 菜 & 2 & 3. 3 \\
\hline チ & ンポン & 2 & 3. 3 \\
\hline ピ. & r - スト & 2 & 3. 3 \\
\hline そ & になし & 2 & 3.3 \\
\hline 7 & ソス料理 & 1 & 1. 7 \\
\hline 茶 & ん蒸 し & 1 & 1. 7 \\
\hline う & $\varepsilon$ ん & 1 & 1. 7 \\
\hline & 付 壮 & 1 & 1. 7 \\
\hline & た い物 & 1 & 1. 7 \\
\hline & 計 & 60 & 100.0 \\
\hline
\end{tabular}


表 5 女子短期大学生のいちばん食べたい物

\begin{tabular}{|c|c|c|}
\hline 食 品 名 & 例 数 & $\begin{array}{c}\text { 百分率 } \\
(\%)\end{array}$ \\
\hline 果 物 & 91 & 17.5 \\
\hline アイスクリーム & 60 & 11.6 \\
\hline 米＼cjkstart料 & 49 & 9.4 \\
\hline 軽 & 47 & 9.0 \\
\hline 肉料 & 44 & 8.5 \\
\hline ヶ - & 42 & 8.1 \\
\hline 母の手料理 & 32 & 6.2 \\
\hline 菓子・デザート & 31 & 6.0 \\
\hline 野 菜 料 理 & 28 & 5.4 \\
\hline とくになし & 16 & 3.1 \\
\hline パ $>I$ & 15 & 2.9 \\
\hline 冷たい飲み物 & 14 & 2.7 \\
\hline 魚 料 理 & 12 & 2.3 \\
\hline 味覚の良いもの & 11 & 2.1 \\
\hline 中 華 料 理 & 6 & 1.1 \\
\hline 卵 料 理 & 6 & 1.1 \\
\hline グラタン料理 & 5 & 1. 0 \\
\hline レストラン料理 & 5 & 1.0 \\
\hline 温 い飲 み物 & 3 & 0.6 \\
\hline み そ 汁 & 2 & 0.4 \\
\hline 計 & 519 & 100.0 \\
\hline
\end{tabular}

表 6 老人クラブ会員男子のいちばん食べたい物

\begin{tabular}{|c|c|c|c|c|}
\hline 食 & 品 & 名 & 例 数 & $\begin{array}{c}\text { 百分率 } \\
(\%)\end{array}$ \\
\hline と & \multirow{5}{*}{ くにな } & ᄂ & 67 & 36.7 \\
\hline 果 & & 物 & 29 & 15.9 \\
\hline 魚 & & 類 & 23 & 12.6 \\
\hline 野 & & 菜 & 19 & 10.4 \\
\hline 肉 & & 類 & 15 & 8.2 \\
\hline 甘 & W & 物 & 6 & 3. 3 \\
\hline 和 & \multirow[t]{2}{*}{ 風米料 } & 理 & 6 & 3. 3 \\
\hline 麵 & & 類 & 4 & 2.2 \\
\hline 大 & \multirow{2}{*}{$\begin{array}{c}\text { 豆 製 } \\
\text { 酒 }\end{array}$} & 品 & 3 & 1. 7 \\
\hline & & & 2 & 1.1 \\
\hline 酢 & \multirow[t]{2}{*}{ の } & 物 & 2 & 1.1 \\
\hline 海 & & 草 & 1 & 0.5 \\
\hline D & \multirow[t]{2}{*}{ ま } & み & 1 & 0.5 \\
\hline お & & 茶 & 1 & 0.5 \\
\hline 中 & \multirow[t]{3}{*}{ 華 料 } & 理 & 1 & 0.5 \\
\hline 食 & & 事 & 1 & 0.5 \\
\hline 油 & & 物 & 1 & 0.5 \\
\hline \multirow[t]{2}{*}{ そ } & の & 他 & 1 & 0.5 \\
\hline & 計 & & 183 & 100.0 \\
\hline
\end{tabular}

男子公務員と女子公務員を比較すると，上位に菓子，果物，肉があることは共通しているが，男子に特い て，とくになしといら者が13.3\%もみられることは, 注目される。

小学生の成績で述べたように, 本調査の質問では, すぐにイメージとして出てこないと, とくになしと答え る傾向を示すのかもしれない。

(3) 女子短期大学生について

女子短期大学 1 年生の「いちばん食べたい物」は, 表 5 に示すように, 果物 (17.5\%), アイスクリーム (11.6\%), 米料理 $(9.4 \%)$, 軽食 $(9.0 \%)$, 肉料理 $(8.5 \%)$ が上位を占めている。

母の手料理, 冷たい飲及物, 味覚的に快い物など, 女子短期大学生においても, 抽象的なるのが $12 \%$ みら れる。

女子短期大学生と20 33歳の地方公務員女子において，「いちばん食べたい物」の分布は，例数が異なるの で，直接的には比較できないが，大体において似た分布を示している。

(4) 老人クラプ会員について

老人クラブ会員男子に猢り「いちばん食べたい物」は，表6亿示すように，とくになし (36.7\%)，果物 (15.9\%), 魚類 $(12.6 \%)$ 野菜 (10.4\%), 肉類 $(8.2 \%)$ が上位を占めている。

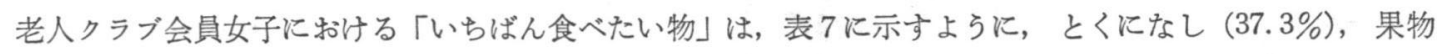
$(24.0 \%)$, 魚類 $(8.2 \%)$, 野菜 $(8.2 \%)$, 和風米料理 $(5.0 \%)$ が上位を占めている。

老人における「いちばん食べたい物」の分布を，男女別に比較すると，ほとんど差はみられない。 
とくに注目されるのは,「いちばん食ベたい物」が，とくになしといら者が $37 \%$ みられることで，老人は食 物に対する関心度が低いのか，あるいは意識としてのイメージが弱いのか，2つの理由が考えられる。

われわれの老人の嗜好調査 $(1972)^{6)}$ では，具体的に食品名を 20 並べて，好きか娧いかを質問したのである が，好きな物は，男は，果物，刺身，天ぷら，すき焼きが上位を占め，女は，果物，ちらしずし，お浸し，刺 身が上位を占めており，本調査の分布とやや異なっている。

具体的な品名ごとに質問する方法が，本調査のよ らに拙象的に「いちばん食べたい物」と質間するよ

りも，好き嫌いを正確に知ることができる。

しかし，拙象的な質問の特徴として，意識的なる のを知ることができる。すなわち，「いちばん食べ たい物」がとくにないと答えた者は，小学生では $13.2 \%$ (男子), $9.3 \%$ (女子), 地方公務員では 13.3 $\%$ (男子), 3.3\% (女子), 女子短期大学生は $3.1 \%$, 老人では $36.7 \%$ (男子), $37.3 \%$ (女子）であり， これは老人特有のパターンかもしれない。今後の榆 討を要することである。

\section{2. いちばん食べたくないもの}

(1) 小学生について

小学生男子に护る「いちばん食べたくない物」は, 表 8 に示すように, 野菜(47.1\%)，とくになし(19.1 $\%)$, 肉 $(11.8 \%)$, 魚 $(5.9 \%)$ というすのが上位 を占めている。

小学生女子に拈ける「いちばん食べたくない物」 は, 表 9 に示すよらに, 野菜 $(41.2 \%)$, とくにな ᄂ $(18.8 \%)$, 肉 $(16.5 \%)$, 和風料理 $(4.7 \%)$ が 表 8 小学生男子のいちばん食べたくない物

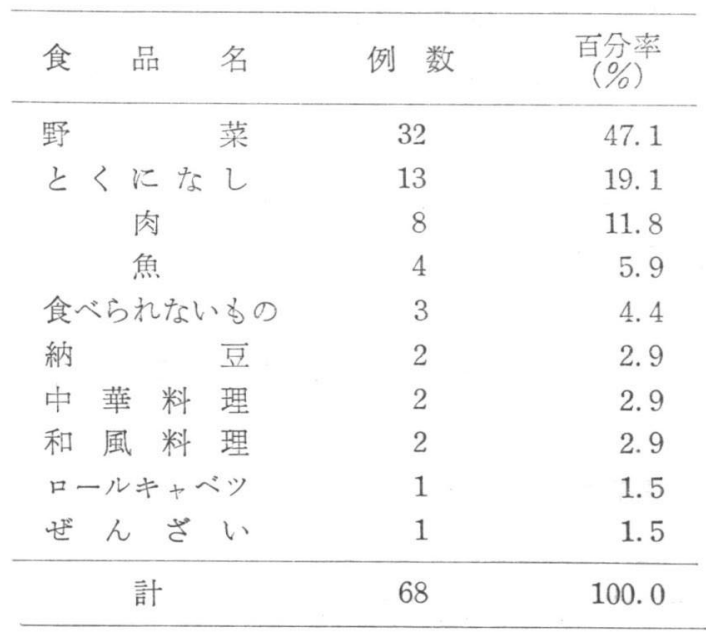

表 7 老人クラブ会員女子のいちばん食べたい物

\begin{tabular}{|c|c|c|}
\hline 食品名 & 例 数 & $\begin{array}{c}\text { 百分率 } \\
(\%)\end{array}$ \\
\hline とくになし & 104 & 37.3 \\
\hline 果 物 & 67 & 24.0 \\
\hline 類 & 23 & 8.2 \\
\hline 野菜 & 23 & 8.2 \\
\hline 和風米料理 & 14 & 5.0 \\
\hline 肉 類 & 9 & 3.2 \\
\hline 菓 & 8 & 2.9 \\
\hline 和 風 料 理 & 7 & 2.5 \\
\hline カへてての食物 & 6 & 2. 1 \\
\hline 味覚の良い物 & 5 & 1.8 \\
\hline 麵 類 & 5 & 1. 8 \\
\hline 栄養のある物 & 3 & 1. 1 \\
\hline 乳 䡛 品 & 2 & 0.7 \\
\hline 油の少ない物 & 1 & 0.3 \\
\hline 洋 風 料 理 & 1 & 0.3 \\
\hline 茶 & 1 & 0.3 \\
\hline そ の & 1 & 0.3 \\
\hline 計 & 279 & 100.0 \\
\hline
\end{tabular}

表 9 小学生女子のいらばん食べたくない物

\begin{tabular}{|c|c|c|c|c|}
\hline 食 & 品 & 名 & 例 数 & $\begin{array}{c}\text { 百分率 } \\
(\%)\end{array}$ \\
\hline 野 & & 菜 & 35 & 41. 2 \\
\hline \multirow[t]{2}{*}{ c } & くにな & L & 16 & 18.8 \\
\hline & 肉 & & 14 & 16.5 \\
\hline 和 & 風 料 & 理 & 4 & 4. 7 \\
\hline チ & - & ズ & 3 & 3. 4 \\
\hline 菓 & & 子 & 3 & 3.4 \\
\hline \multirow[t]{2}{*}{ 魚 } & 介 & 類 & 2 & 2.4 \\
\hline & 畉 & & 2 & 2.4 \\
\hline ス & - & 70 & 2 & 2.4 \\
\hline あ & 3 w & 物 & 1 & 1. 2 \\
\hline 納 & & 豆 & 1 & 1. 2 \\
\hline \multirow{2}{*}{\multicolumn{3}{|c|}{$\begin{array}{l}\text { パイナップル午詰 } \\
\text { 食ベられないもの }\end{array}$}} & 1 & 1.2 \\
\hline & & & 1 & 1. 2 \\
\hline \multicolumn{3}{|c|}{ 計 } & 85 & 100.0 \\
\hline
\end{tabular}


上位を占めている。

前述のように，本調査においては，「いちばん食ぺたくない物」といら質問のため，多くの食品名が記入さ れている。これを表 1 にまとめるために，ピーマン，キャベッ，にんじん，パセリなどと記入されたものを野 菜として一括分類したもので, 回答の中には, 野菜という表現は使用されていない。

以下，女子短期大学生，地方公務員に㧤いて同様の分類を行っている。

いずれにしても，小学生の男女とも，野菜が「食べたくない物」の首位を占めていることは問題である。

わが国の栄養改善のひとつのテーマとして，野菜の摂取は，永い間重点的に指導されたはずである。実際に 野菜の摂取が不十分であるとすれば，大きな課題である。

われわれの学校給食調查3) に拈いても, 嫌いな食品のトップにピーマン, にんじん, グリンピースがみら れ，学年による差がみられなかった。

野菜がただ意識として嫝いなのか, 日常生活においても摂取していないかは, 本調査及び学校給食調査 は不明であり, 重要な課題であるので, 改めて, 調査を行い検討したい。

(2) 地方公務員について

18～28歳の地方公務員男子に拈ける「いちばん食べたくない物」は，表10に示すよらに野菜 $(24.8 \%)$, とく になし $(19.7 \%)$, ゴキブリ，マムシ，蛇などの食物でないもの $(16.2 \%)$, 魚 $(9.8 \%)$, 肉 $(6.4 \%)$ が上位 を占めている。

20３3歳の地方公務員女子に拈ける「いちばん食べたくない物」は，表11に示すように，野菜 $(21.6 \%)$ ， 肉 $(16.6 \%)$ ，納豆 $(13.3 \%)$ ，とくになし $(11.7 \%)$ が上位を占めている。

すなわち，今回の調査対象の地方公務員男子の「いちばん食べたい物」は，肉，果物であり，「食べたくな

表 10 18～28歳の地方公務員男子のいちばん 食べたくない物

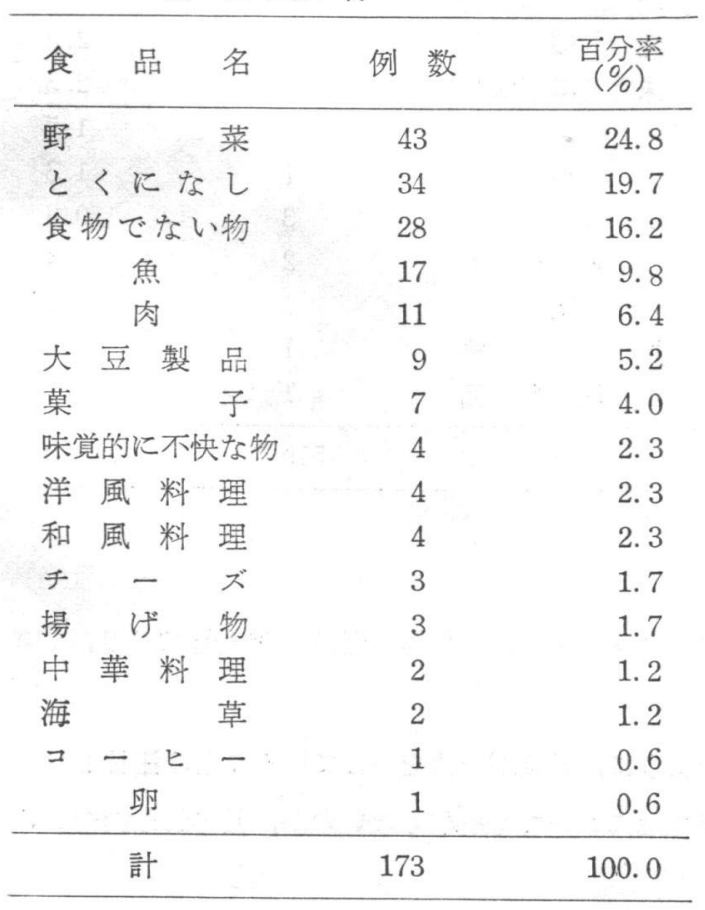

い物」は，野菜であり，同じく地方公務員女子の「い ちばん食べたくない物」は, 野菜, 肉, 納豆という

表 1120 33歳の地方公務員女子のいちばん 食ベたくない物

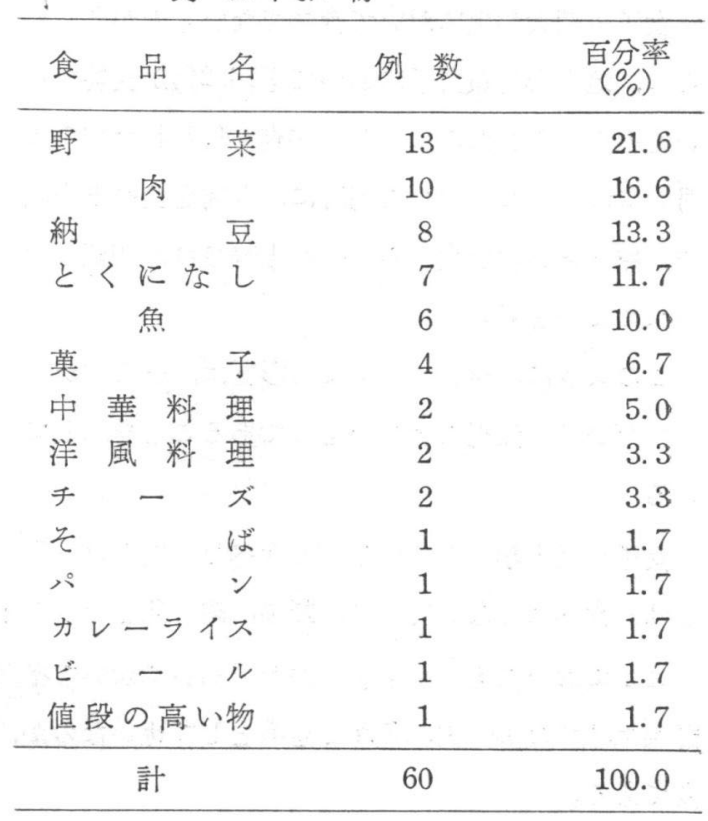




\section{ことになる。}

以上のように, 小学生と同様, 地方公務員男女とも, 野菜を「いちばん食べたくない」と答觉た者が上位を 占めていることは注目される。

すでに述べたように, 意識として嫌いなのか, 日常生活においても摂取しないのか, これも大きな課題をも っている。

実態を知るには，集団給食あるいはレストランなどで，摂食行動の観察などが良いかもしれない。

地方公務員女子の「いちばん食べたくない物」に納豆が $13.3 \%$ みられ，小学生は $1.2 \%$ (男子), $2.9 \%$ (女 子), 老人クラブ会員男子は $1.1 \%$, 地方公務員男子 (18２8歳) はまったくみられないのに比較すると, 高率 である。

しかし，さきにわれわれが調査した地方公務員男子 ${ }^{8)}$ (40～60歳）でも，「いちばん食べたくない物」に納 豆、にんじんが上位を占めていた。

このような成績が北九州地方で特有かどうかは, 今後の研究課題である。

(3) 女子短期大学生について

女子短期大学 1 年生における「いらばん食べたく ない物」は, 表12に示すように, 野菜 (22.9\%),

肉 $(18.1 \%)$, 魚 $(11.9 \%)$ ，とくになし $(11.4 \%)$ ， 食物でない物 $(10.6 \%)$ ， と答えた者が上位を占め ている。

女子短期大学生と 20 33歳の地方公務員女子にお ける「いちばん食べたくない物」を比較すると，女 子短期大学生において食物でないるのが $10.6 \%$ る られるのを除くと，大体において似た分布を示して いる。

女子短期大学生において食物でないものが多くみ られ，地方公務員男子においても16.2\%が食物でな いものがみられたのは, この調査が行われた約 1 カ 月前に，テレビと映画で同時に，人肉を食べる場面 や，蛇やとかげを食べる場面が上映され，印象づけ られたためと考える。

このように, マスコミによる影響は, 一時的かも 表 12 女子短期大学生のいちばん食べたくない物

\begin{tabular}{|c|c|c|c|c|}
\hline 食 & 品 & 名 & 例 数 & $\begin{array}{c}\text { 百分率 } \\
(\%)\end{array}$ \\
\hline \multirow[t]{3}{*}{ 野 } & & 菜 & 119 & 22.9 \\
\hline & 肉 & & 94 & 18.1 \\
\hline & 魚 & & 62 & 11.9 \\
\hline \multirow{2}{*}{\multicolumn{3}{|c|}{$\begin{array}{l}\text { とくになし } \\
\text { 食物でない物 }\end{array}$}} & 59 & 11. 4 \\
\hline & & & 55 & 10.6 \\
\hline \multicolumn{2}{|c|}{ 菓 } & 子 & 29 & 5.6 \\
\hline \multirow{3}{*}{$\begin{array}{l}\text { 大 } \\
\text { 寮 } \\
\text { 軽 }\end{array}$} & 豆 製 & 品 & 21 & 4.1 \\
\hline & の 食 & 事 & 16 & 3.1 \\
\hline & & 食 & 16 & 3.1 \\
\hline & 製 & 品 & 12 & 2.3 \\
\hline \multicolumn{3}{|c|}{ 味覚的に不快な物 } & 12 & 2.3 \\
\hline \multicolumn{3}{|c|}{ 卵 } & 9 & 1.7 \\
\hline 米 & 料 & 理 & 7 & 1.3 \\
\hline & $=-$ & x & 3 & 0.6 \\
\hline \multirow{2}{*}{\multicolumn{2}{|c|}{$\begin{array}{c}\text { 中 華 料 } \\
\text { 薬 }\end{array}$}} & 理 & 2 & 0.4 \\
\hline & & & 1 & 0.2 \\
\hline \multicolumn{2}{|c|}{ 果 } & 物 & 1 & 0.2 \\
\hline \multicolumn{2}{|c|}{ 調 理 食 } & 品 & 1 & 0.2 \\
\hline & 計 & & 519 & 100.0 \\
\hline
\end{tabular}

知れないが，無視できないものであることを示して いる。

女子短期大学生の「いちばん食べたい物」は, 果物, アイスクリーム, 米料理, 軽食, 肉料理であり,「い ちばん食ベたくない物」は, 野菜, 肉, 魚ということになる。

ここに执いても, 小学生, 地方公務員に批いて指摘したように, 野菜が上位を占めていることは注目され, 野菜だけてなお，肉，魚など意識として嫌いなのか，日常生活においても摂取しないのか，具体的な調查が必 要である。 
表 13 老人クラブ会員男子のいちばん 食べたくない物

\begin{tabular}{|c|c|c|c|}
\hline 食品 & 品 名 & 例 数 & $\begin{array}{c}\text { 百分率 } \\
(\%)\end{array}$ \\
\hline$z<v$ & になし & 95 & 51.9 \\
\hline 魚 & 類 & 18 & 9.8 \\
\hline \multicolumn{2}{|c|}{$\begin{array}{l}\text { 味覚や感覚的に } \\
\text { 不快な物 }\end{array}$} & 17 & 9.3 \\
\hline 野 & 菜 & 12 & 6.7 \\
\hline 肉 & 類 & 12 & 6.7 \\
\hline 油っ & こい物 & 8 & 4.4 \\
\hline 麵 & 類 & 4 & 2.2 \\
\hline カ & - & 2 & 1.1 \\
\hline 䣫 & 物 & 2 & 1. 1 \\
\hline \multirow[t]{2}{*}{ 納 } & 豆 & 2 & 1.1 \\
\hline & 卵 & 2 & 1.1 \\
\hline 調 理 t & 加工 品 & 2 & 1. 1 \\
\hline ハீ & ソ & 1 & 0.5 \\
\hline 佃 & 煮 & 1 & 0.5 \\
\hline 牛 & 乳 & 1 & 0.5 \\
\hline ダ V & $\exists$ 汁 & 1 & 0.5 \\
\hline 果 & 物 & 1 & 0.5 \\
\hline \multirow{2}{*}{\multicolumn{2}{|c|}{$\begin{array}{l}\text { 消化の悪い物 } \\
\text { 老化をはやめる物 }\end{array}$}} & 1 & 0.5 \\
\hline & & 1 & 0.5 \\
\hline & 計 & 183 & 100.0 \\
\hline
\end{tabular}

表 14 老人クラブ会員女子のいちばん 食べたくない物

\begin{tabular}{|c|c|c|c|}
\hline 食品 & 品 名 & 例 数 & $\begin{array}{c}\text { 百分率 } \\
(\%)\end{array}$ \\
\hline$\varepsilon<k$ & になし & 139 & 49.8 \\
\hline 肉 & 類 & 31 & 11. 1 \\
\hline \multicolumn{2}{|c|}{$\begin{array}{l}\text { 味覚や感覚的に } \\
\text { 不な物 }\end{array}$} & 23 & 8.2 \\
\hline 魚 & 類 & 16 & 5.7 \\
\hline 油っ & こい物 & 13 & 4.6 \\
\hline 野 & 菜 & 12 & 4.3 \\
\hline \multicolumn{2}{|c|}{ 香辛料・刺激物 } & 9 & 3.2 \\
\hline 果 & 物 & 6 & 2.1 \\
\hline 大 豆 & 製 品 & 5 & 1.8 \\
\hline 䣫 & 物 & 5 & 1.8 \\
\hline 乳量 & 品 & 4 & 1. 4 \\
\hline い か & もの & 3 & 1.1 \\
\hline \multirow{3}{*}{\multicolumn{2}{|c|}{$\begin{array}{ll}\text { 菓 } & \\
\text { 留 } \\
\text { 酒 }\end{array}$}} & 3 & 1.1 \\
\hline & & 2 & 0.7 \\
\hline & & 2 & 0.7 \\
\hline \multirow{4}{*}{\multicolumn{2}{|c|}{$\begin{array}{llll}\text { そ } & & \text { ば } \\
\text { 冷 } & \text { 凍 } & \text { 食 } & \text { 品 } \\
\text { 洋 } & \text { 風 } & \text { 料 } & \text { 理 } \\
\text { 汁 } & & & \text { 物 }\end{array}$}} & 1 & 0.4 \\
\hline & & 1 & 0.4 \\
\hline & & 1 & 0.4 \\
\hline & & 1 & 0.4 \\
\hline \multicolumn{2}{|c|}{ ホルモン料理 } & 1 & 0.4 \\
\hline \multicolumn{2}{|c|}{ 山 菜 料 理 } & 1 & 0.4 \\
\hline \multicolumn{2}{|c|}{ 計 } & 279 & 100.0 \\
\hline
\end{tabular}

(4) 老人クラプ会員について

老人クラブ会員男子に括ける「いちばん食べたく

ない物」は, 表13に示すように, とくになし (51.9\%), 魚類 $(9.8 \%)$, 塩辛い物, 辛い物, 甘い物，ふたい 物という味覚や感覚的に不快な物 $(9.3 \%)$, 野菜 $(6.7 \%)$, 肉類 $(6.7 \%)$ が上位を占めている。

老人クラプ会員女子における「いちばん食べたくない物」は，表14に示す上うに，とくになし(49.8\%)，肉 類 $(11.1 \%)$, 味覚や感覚的に不快な物 (8.2), 魚類 (5.7\%), 油っこい物 $(4.6 \%)$ が上位を占めている。

老人クラブ会員に拈ける「いちばん食べたくない物」の男女に上る差は，著明でない。

「いちばん食べたくない物」を「いちばん食べたい物」と同椂にとくになしと答壳たが首位を示しているこ とは，特徴的である。

「いちばん食べたくない物」を，とくになしと答光た者を，年齢別に比較すると，小学生は 18.8 19.1\%， 地方公務員 11.7 19.7\%, 女子短期大学生は $11.4 \%$, 老人は $49.8 \sim 51.9 \%$ あ゙あ, これも老人がもっとも多い ことは注目され, その理由は今後の研究課題である,

われわれの老人の喈好調査 $(1972)^{6)}$ では, 嫌いな食品は, 男は八厶, ケーキ, 天ぷら, 女は八厶, 牛乳, 天ぷらが上位を占めており, 油っこいもの, 牛乳が嫌われているのがみとめられた。

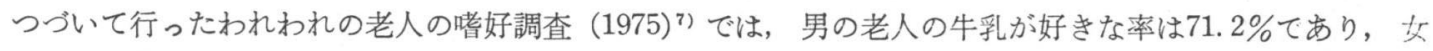
の老人の牛乳が好きな率は $50.9 \%$ であり, 男女差をみとめた。

本調査においては, 牛乳が嫌いというるのは, 男はわずか 1 例, 女は 4 例沉いすぎず, 前の調査とはかな 
り異なった分布を示している。

本調査に持ける老人の「いちばん食べたい物」は, とくになしがもっとも多く, 次いで果物, 野菜, 肉, 魚 であり,「いちばん食べたくない物」る, とくになしがもっとも多く, 魚, 野菜, 肉, 塩辛い物, 辛い物, か たい物といった味覚や感覚的に不快な物が多いことを示している。

\section{まと め}

われわれは, 北九州市における小学生153例（男は68例, 女は85例), 女子短期大学生519例, 地方公務員233: 例（男は173例，女は60例)，老人クラブ会員462例（男は183例，女は279例）, 計1,367例について，「いちばん 食べたい物」「いちばん食べたくない物」はなにか質問した。

1）小学生に和ける「いちばん食べたい物」は, 男女とも肉料理, 果物, アイスクリームが上位を占め, 「いちばん食べたくない物」は，野菜が首位を占めていることは注目される。野菜が嫌いなのは，意識だけの， ものか日常生活においても摂取していないかは, 今後の課題である。

2）地方公務員男子に括ける「いちばん食ベたい物」は，肉，果物であり，「いちばん食べたくない物」は 野菜であり, 地方公務員女子の「いちばん食べたい物」は菓子, 果物であり,「食べたくない物」は野菜, 肉, 納豆である。小学生と同様に野菜の嫝いな理由は, 今後の課題である。

3）女子短期大学生の「いちばん食べたい物」は，果物，アイスクリームであり，「いちばん食べたくない 物」は野菜, 肉, 魚である。

4）老人の「いちばん食べたい物」は，男女とも，果物，肉，魚が上位を占め，「いちばん食べたくない物」 は, 魚, 野菜, 肉, 塩辛い物, 辛い物, かたい物といった味覚や感覚的に不快なものが上位を占めていること. が特徴的である。

稿を終るに当だり, 本調査に御協力をいただいた北九州市立引野小学校, 九州女子短期大学, 北九州市市役: 所, 戸烟老人クラブの各位に深く感謝します。

\section{交献}

1）園田直人, 江口加代子 : 栄養学雑誌, 28 (4), 149 (1970)

2) 園田真人, 高橋純子 : 臨床栄養, 34 (6), 649 (1969)

3）園田真人, 大和昭恵 : 健康教室, 307, 41 (1976)

4) 西見真知子 : 保健の科学, 12 (6), 315 (1970)

5）園田真人，江口加代子 : 臨床栄養，40（3)，335（1972）

6) 園田真人，野口球子：臨床栄養，41 (4)，497 (1972)

7）園田真人, 石橋幸子：保健の科学, 17 (4), 245 (1975)

8）園田真人：臨床栄養, 56 (3), 271 (1980)

9）園田真人：食品工業, 12, 57 (1972)

10）園田真人：日本公衛誌, 18 (10), 379 (1971)

(受付：昭和55年 9 月 20 日)， 